\section{AB1401-HPR AN EXPLORATORY STUDY EVALUATING FEASIBILITY AND EFFECTIVENESS OF TWO DIFFERENT EXERCISE PROGRAMS IN SYSTEMIC SCLEROSIS ASSOCIATED MICROSTOMIA}

E Sydow $^{1}$, S. Arat ${ }^{2}$, S. Severi ${ }^{1}$, R. Westhovens ${ }^{1,2}$, J. Lenaerts ${ }^{1}$, E. De Langhe ${ }^{1,2}$. ${ }^{1}$ Rheumatology, University Hospitals Leuven; ${ }^{2} \mathrm{KU}$ Leuven Department of development and regeneration, Skeletal Biology and Engineering Research Center, Leuven, Belgium

Background: Systemic sclerosis (SSc) is a severe chronic connective tissue disease with a high disease burden. Oral involvement with impaired oral aperture (microstomia) is frequent and associated with impaired food intake, oral hygiene and secondary dental problems. Preventive measures through mouth-stretching and oral augmentation exercises have been shown to reverse the progression of microstomia.

Objectives: This exploratory study assesses the effectiveness and feasibility of two different exercise approaches designed to increase oral aperture.

Methods: Two groups had to exercise for $10 \mathrm{~min}, 3$ times/day for 3 months. Group A exercised with a passive jaw motion device (Therabite), and Group B did mouth-stretching exercises. Patients were contacted 4 times by telephone to address encountered problems. The subjects used an exercise diary to document compliance. Patients were evaluated at baseline, 3 months (period without intervention), 6 months (at the end of the treatment after 3 months of intervention) and 9 months (follow-up).

Results: At present, 9 patients (Therabite $n=4$, mouth-stretching exercises $\mathrm{n}=5$ ) were included and recruitment is ongoing. Seven patients completed the study and increase of oral aperture was observed in all patients in both groups. In the Therabite group, after 3 months of exercise, increase of oral aperture was $9,2,9$ and $10 \mathrm{~mm}$. In the mouth-stretching exercise group the increase of oral aperture was 11,10 and $4 \mathrm{~mm}$ after 3 months. The compliance, measured as the ratio of executed exercises relative to the planned number of exercises was $95,2 \%, 85,7 \%, 98,9 \%$ and $63,7 \%$ in the Therabite group and $97,4 \%, 48,6 \%$ and $68,3 \%$ in the mouth-stretching exercise group.

Conclusions: An increase of oral aperture is observed in all patients after 3 months of exercising with the Therabite device as well as after mouth-stretching exercises. No clear differences are observed between both groups, but the study was not designed nor powered for this. Remarkably, a high compliance for the treatment regime was observed in most patients.

\section{REFERENCES:}

[1] Agarwal SK. The genetics of systemic sclerosis. Discov Med. 2010 Aug;10 (51):134-43.

[2] Alantar A, Cabane J, Hachulla E, Princ G, Glinist D, Hassin M, Sorel M, Maman L, Pilat A, Mouthon L. Recommendations for the Care of Oral Involvement in Patients With Systemic Sclerosis. Arthritis Care and Research. VOL. 63. No8, august 2011, pp 1126-1133.

[3] Albilia JB, Lam DK, Blanas N, Clokie CML, Sandor GKB. Small Mouths...Big Problems? A review of Scleroderma and its Oral Health Implications. www.cda-adc.ca/jcda. November 2007, vol 73, no 9.

[4] Maddali-Bongi S, Landi G, Galluccio F, Del Rosso A, Miniati I, Conforti M. L, Casale R, Matucci-Cerinic M. The rehabilitation of facial involvement in systemic sclerosis: efficacy of the combination of connective tissue massage, Kabat's technique and kinesitherapy: a randomized controlled trial. Rheumatol Int (2011 31:895-901.

[5] Pizzo G, Scardina GA, Mesina P. Effects of nonsurgical exercise program on the decreased mouth opening in patient with systemic sclerosis. Clin Oral Invest 2003; 7:175-178.

Disclosure of Interest: None declared

DOI: 10.1136/annrheumdis-2018-eular.3722

\section{AB1402-HPR VALIDITY OF BIODEX BALANCE SYSTEM IN FIBROMYALGIA PATIENTS}

F Söke $^{1}$, A. Güclü Gündüz ${ }^{1}$, C. Gülsen ${ }^{1}$, Y. Aydın ${ }^{1}$, K. Cekim ${ }^{1}$, D. Akcalı2. ${ }^{1}$ Faculty of Health Sciences, Department of Physiotherapy and Rehabilitation; ${ }^{2}$ Pain Clinic, School of Medicine, Gazi University, Ankara, Turkey

Background: Fibromiyalgia (FM) patients are commonly suffer from balance problems and increased fall frequency. However, validity of any measurement tool has not been determined in clinical trials. Modified Clinical Test of Sensory Interaction and Balance Test (M-CTSIB) is a simple and easily administered test.

Objectives: The aim of the study was to investigate the validity and reliability of the M-CTSIB in FM patients.

Methods: Twenty-one FM patients and 15 age matched controls were evaluated M-CTSIB. M-CTSIB was evalueted by Biodex-BioSway ${ }^{\text {TM }}$ (Biodex Inc., Shirley, New York)]. M-CTSIB evaluates the relationship between balance and visual, somatosensory and vestibular system. Tests carried out were 4 conditions, condition-1: eyes open-firm surface, condition-2: eyes closed-firm surface, condition 3: eyes open-foam surface, and condition 4: eyes closed-foam surface, for $30 \mathrm{~s}$ intervals with two repetitions. Body oscillations of the participants were calculated by the system and Sway Index scores obtained. High scores indicate high postural sway of the test subject.

Results: The results of this study, FM patients had significantly impaired balance in all conditions of M-CTSIB compared to controls $(p<0.05)$. Discriminatory power of all subcomponents of M-CTSIB between groups was excellent. The ROC areas under the curves were 0.803 for condition-1, 0.757 for condition-2, 0.833 for condition-3, 0.776 for condition-4 (AUC=0.803, $A \cup C=0.757, A \cup C=0.833, A \cup C=0.776$, respectively).

Conclusions: These results suggest that FM may lead to increase balance problems. M-CTSIB has been proved to be valid, objective and clinically useful method to detect balance impairments in FM patients.

Disclosure of Interest: None declared

DOI: 10.1136/annrheumdis-2018-eular.5324

\section{AB1403-HPR INVESTIGATION OF THE VALIDITY OF BETY SCALE IN PATIENTS WITH RHEUMATOID ARTHRITIS}

F.B Oflaz ${ }^{1}$, G. Arın ${ }^{1}$, N.B. Karaca ${ }^{1}$, S. Apraş Bilgen ${ }^{2}$, E. Ünal'. ${ }^{1}$ Department of Physiotherapy and Rehabilitation, Hacettepe University Faculty of Health Sciences; ${ }^{2}$ Department of Internal Medicine-Rheumatology, Hacettepe University Faculty of Medicine, Ankara, Turkey

Background: The Cognitive Exercise Therapy Approach is a biopsychosocial model for the patients with rheumatic diseases. ${ }^{1}$ Cognitive Exercise Therapy Approach Scale (the authors request that the abbreviation stay as "BETY" as the original in Turkish) is a scale that evaluates the biopsychosocial status of the patients with rheumatic diseases. This scale needs validation studies in different rheumatic diseases. ${ }^{2}$

Objectives: The aim of this study is to investigate the validation of the BETY scale in patients with Rheumatoid Arthritis (RA).

Methods: 120 RA patients were included in this study. To determine the functional status of the patient Health Assessment Questionnaire (HAQ) was used. Rheumatoid Arthritis Quality of Life Scale (RAQoL) and 36Item Short Form Survey (SF-36) were used to measure quality of life. Hospital Anxiety and Depression Scale (HADS) was used to determine anxiety and depression levels. BETY scale was used to in addition to this questionaires for the validation.

Results: 120 RA patients including 13 men and 107 women were participated in the study. The average age of the participating patients was $28,47 \pm 11,39$ years and the body mass index was $28.4 \pm 6,56$. There was a very high correlation between the BETY scale and RAQoL $(r=0,817$, $\mathrm{p}<0,001)$. There was high correlation between the BETY scale and

Abstract AB1403HPR - Table 1. Correlations

\begin{tabular}{|c|c|c|c|c|c|c|c|c|c|c|}
\hline & & RAQoL & $\begin{array}{c}\text { SF-36 } \\
\text { PF }\end{array}$ & $\begin{array}{c}\text { SF-36 } \\
\text { RL }\end{array}$ & $\begin{array}{c}\text { SF-36 } \\
\text { RLE }\end{array}$ & $\begin{array}{c}\text { SF-36 } \\
\text { P }\end{array}$ & $\begin{array}{l}\text { SF-36 } \\
\text { GHP }\end{array}$ & $x H A Q$ & $\begin{array}{l}\text { HADS } \\
\text { Anxiety }\end{array}$ & $\begin{array}{c}\text { HADS } \\
\text { Depression }\end{array}$ \\
\hline$\overline{B E T Y}$ & $r$ & 0817 & $-0,576$ & $-0,525$ & $-0,598$ & $-0,610$ & $-0,420$ & 0606 & 0617 & 0597 \\
\hline $\bar{p}$ & 0000 & 0000 & 0000 & 0000 & 0000 & 0000 & 0000 & 0000 & 0000 & \\
\hline
\end{tabular}

PF: Physical Functioning, RL: Role Limitations, RLE: Role Limitations Due to Emotioal, P: Pain, GHP: General Health Perception 